\title{
Trace Elements in Serum Samples of Patients with Multiple Sclerosis
}

\author{
By Mohsen Janghorbani* \\ Vahid Shaygannejad" \\ Masoud Hakimdavood ${ }^{*}$ \\ Mehri Salari ${ }^{+}$
}

\begin{abstract}
The aim of this study was to compare trace element concentrations in plasma samples of patients with multiple sclerosis (MS) with healthy controls to ascertain the association of these trace elements with MS. A total of 55 patients with MS 15-70 years old and 90 healthy individuals without MS were investigated. Using inductively coupled plasma atomic emission spectrometry, we determined 24 elements in blood plasma from MS patients and a control group. Compared to subjects without MS, a lower concentration level of calcium (Ca) (58.3 $\mathrm{mg} / \mathrm{L}$ vs. $70.4 \mathrm{mg} / \mathrm{L}, P<0.001)$, potassium $(\mathrm{K})(457.7 \mu \mathrm{g} / \mathrm{L}$ vs. $546.9 \mu \mathrm{g} / \mathrm{L}, P<0.001)$, sulphur (S) (250.1 mg/L vs. $273.5 \mathrm{mg} / \mathrm{L}, P<0.001))$, sodium $(\mathrm{Na})(2644.9 \mu \mathrm{g} / \mathrm{L}$ vs. $2783.2 \mu \mathrm{g} / \mathrm{L}$, $(P<0.001)$, phosphor $(P)(271.3 \mathrm{mg} / \mathrm{L}$ vs. $300.5 \mathrm{mg} / \mathrm{L}, P<00.001)$ and zinc $(\mathrm{Zn})(235.2 \mu \mathrm{g} / \mathrm{L} \mathrm{vs}$. $288.1 \mu \mathrm{g} / \mathrm{L}, \mathrm{P}<0.001)$ were found in MS patients. Lower concentration levels of $\mathrm{Ca}, \mathrm{K}$ and $\mathrm{Zn}$ have stronger associations with MS. The results on the whole indicate the involvement of $C a$, $K, S, N a, P$ and $Z n$ (decreased serum level) in MS that may cause or result from the disease. This warrants further study.
\end{abstract}

Keywords: Blood, Chemical elements, Multiple sclerosis, Oxidative damage, Trace elements

\section{Introduction}

Multiple sclerosis (MS) is an inflammatory, demyelinating, immunemediated and debilitating disease that affects young adults and provokes disability and neurological symptoms (Clanet and Brassat 2000, Richards et al. 2002). The causes and mechanism of this disease are still not completely clear.

Despite the low concentration of trace elements in the body, they played an important role in various metabolic events, the development of the nervous system, myelination of the nerve fibers, and neural excitability (Wallwork and Sandstead 1993). Abnormalities in transition metals and other trace elements in biological matrices levels have been reported in several neurological diseases, including Alzheimer disease, Parkinson disease, amyotropic lateral sclerosis and MS (Rynan et al. 1978, Schulten et al. 1983, Sayre et al. 2000, Bomboi et al. 2005, Forte et al. 2005a, Exley and House 2010, Vinceti et al. 2013, Nicoletti et al. 2011, Valera et al. 2014). Magnesium has long been known as a

\footnotetext{
* Professor of Epidemiology, Department of Epidemiology and Biostatistics, School of Public Health, Isfahan University of Medical Sciences, Iran.

${ }^{\dagger}$ Professor of Neurology, Department of Neurology and Isfahan Neurosciences Research Center Isfahan University of Medical Sciences, Iran.

* Technologist, Isfahan Petroleum Refinery, Iran.

+ Assistant Professor of Neurology, Department of Neurology and Isfahan Neurosciences Research Center, Isfahan University of Medical Sciences, Iran.
} 
neurotoxic trace element (Nicoletti et al. 2011). Exposure to high concentrations of aluminum in workers may have negative effects on the central nervous system (Iregren et al. 2001). Copper, iron and manganese can act as pro-oxidant agents by catalyzing free radical reactions, leading to severe injuries in brain cells (Kienzl et al. 1999). Copper is needed for the enzyme reactions which are involved in the production of ATP, and for the transmission of impulse in the nerves and the muscles (Smith et al. 1989). Cadmium and mercury have been shown able to disrupt mitochondria of neuronal cells by increasing intracellular reactive oxygen species which directly inhibit neural Janus (Jak) kinase tyrosine kinase activity (Monroe and Halvorsen 2009). Zinc ( $\mathrm{Zn})$ is also an antioxidant which protects the cell membranes and myelin.

Information concerning the concentration of metals and trace elements in the blood of MS patients is nonetheless scarce. Whether or not trace elements are of significance in MS is unknown. From a clinical point of view it is important to clarify the role of these elements in association with MS. Our study contributes to this issue by comparing 24 trace element concentrations of patients with MS with healthy controls to ascertain the potential role of these elements as markers for this pathology.

\section{Subjects and Methods}

Between March 2010 and March 2011, 55 (8 men and 47 women) MS patients aged 15-70 who sought treatment for MS at our neurology outpatient clinics of Isfahan University of Medical Sciences, Iran, were evaluated. MS was diagnosed according to the McDonald criteria (Polman et al. 2005). Subjects had to be ambulatory with a Kurtzke Expanded Disability Status Scale (EDSS) (Kutzke 1983) of $\leq 5.5$ with at least one year of natural course of the disease. The group of MS patients was compared with a control group of 95 (28 men and 67 women) healthy adults without known neurological diseases or deficits. Healthy controls were volunteers employed at the Isfahan University of Medical Sciences. None of the participants in the study have had known occupational exposure to trace elements. Subjects were excluded from the study if they had cardiac, respiratory, renal or hepatic disorders; intestinal absorption abnormalities; active infections; thyroid hormones or lithium therapy; intake of vitamin or mineral supplements; vegetarian dietary habits; consumption of any psychoactive drugs other than MS medication; artificial metallic body parts.

The study was approved by the institutional ethical committee of the Isfahan University of Medical Sciences, Iran and participants gave written, informed consent.

After overnight fasting and drug withdrawal, blood samples were taken from all subjects in accordance with the standard procedures. All samples were stored deep-frozen at $-20^{\circ} \mathrm{C}$ until analysis. Maximum care was taken to avoid trace element contamination of the samples. All the plastic containers were 
previously washed in $10 \% \mathrm{HNO} 3$ for $24 \mathrm{hrs}$ and then repeatedly rinsed with deionized water. The efficacy of this cleansing procedure was checked for the release of the metals under study.

The concentrations of 24 trace elements were determined by inductively coupled plasma atomic emission spectrometry (ICP-AES) using a highresolution ICP-AES Optima 5300V spectrometer (Perkin-Elmr, Norwalk, CT, USA) equipped with a AS93 plus auto-sampler. The instrument was equipped with a concentric Meinhart nebulizer connected to a Scott PFA spray chamber, platinum skimmer and interface cones and a quartz burner with a quard electrode. The nebulizer argon gas flow rate was adjusted to give a stable signal with a maximum intensity for the nuclides ${ }^{7} \mathrm{Li},{ }^{115} \mathrm{In}$ and ${ }^{238} \mathrm{U}$. All chemical analyses were performed at the Isfahan petroleum refinery laboratory.

\section{Statistical Analysis}

Since available data on the effects of trace elements on patients with MS are not sufficient for an exact statistical sample size calculation, the study was designed as a pilot study with a priori determined sample size of $50 \mathrm{MS}$ patients in case group and 100 healthy individuals in a healthy control group.

Comparison between the groups was made using Mann-Whitney U tests. Age-adjusted means were calculated and compared using general linear models. Comparisons between proportions were undertaken using the chisquare or Fisher's exact test. Pearson's correlation analysis was performed for investigation of the association between the trace elements. A logistic regression analysis was used for the calculation of individual metal and trace elements effects on MS, adjusting for age and gender. Results are expressed as a mean (standard error [SEM]). All tests for statistical significance were twotailed, and performed assuming a type I error probability of $<0.05$. The analyses were undertaken using SPSS for Windows (SPSS Inc., Chicago, IL, USA).

\section{Results}

Differences in distribution of characteristics among 55 MS patients and 95 healthy controls are shown in Table 1. MS patients were younger and were less likely to be men than those without MS. The mean (SD) age of MS patients was 31.6 (10.4) years and for persons without MS 45.1 (16.8). The mean (SD) EDSS was 3.0 (1.9) in the MS group, with a mean duration of disease of 5.3 (5.3) years. Twenty-three patients had a relapsing-remitting MS course, 10 patients had primary progressive and in 13 patients the disease showed secondary progression. Most MS patients $(54.5 \%)$ received interferon beta. Participants also received mitoxantrone (14.5\%) or immunosuppressive drugs $(30.9 \%)$. 
Table 1. Characteristics of Multiple Sclerosis (MS) Patients and Control Subjects without MS

\begin{tabular}{|l|c|c|c|}
\hline \multicolumn{1}{|c|}{ Characteristic } & $\begin{array}{c}\text { MS } \\
\text { (N=55) }\end{array}$ & $\begin{array}{c}\text { No MS } \\
\text { (N=90) }\end{array}$ & \multirow{2}{*}{ P-value } \\
\hline & Mean (SEM) & Mean (SEM) & \\
\hline Age (yr.) & $31.6(2.0)$ & $45.1(1.6)$ & $<0.001$ \\
\hline EDSS & $3.0(0.25)$ & - & - \\
\hline Duration of MS (yr.) & $5.3(0.72)$ & - & - \\
\hline Gender, N (\%) & & & \\
\hline Men & $8(14.5)$ & $28(29.5)$ & $<0.05$ \\
\hline Women & $47(85.5)$ & $67(70.5)$ & - \\
\hline Multiple sclerosis subtypes, N (\%) & & & \\
\hline Relapsing-remitting & $23(50.0)$ & - & - \\
\hline Secondary progressive & $13(28.3)$ & - & - \\
\hline Primary progressive & $10(21.7)$ & - & - \\
\hline Concomitant medications, N (\%) & & & \\
\hline Interferon beta & $30(54.5)$ & - & - \\
\hline Mitoxantrone & $8(14.5)$ & - & - \\
\hline Immunosuppressive drug & $17(30.9)$ & - & - \\
\hline
\end{tabular}

Notes: $\mathrm{SEM}=$ standard error of the mean; EDSS = expanded disability status scale; $\mathrm{CI}=$ confidence interval; $\mathrm{N}=$ number; $* \mathrm{P}<0.05, * \mathrm{P}<0.05, * * \mathrm{P}<0.001$.

Table 2 shows the concentrations of the 24 elements in blood plasma. Those with MS had slightly higher concentration levels of silver (Ag), aluminium $(\mathrm{Al})$, magnesium $(\mathrm{Mg})$, antimony $(\mathrm{Sb})$, silicon $(\mathrm{Si})$, chromium $(\mathrm{Cr})$ and copper $(\mathrm{Cu})$. Although the average concentration level of $\mathrm{Ag}, \mathrm{Al}, \mathrm{Mg}, \mathrm{Sb}$, and $\mathrm{Cr}$ were significantly greater in MS patients, the differences were small and not clinically relevant. The level of calcium $(\mathrm{Ca})$, iron $(\mathrm{Fe})$, potassium $(\mathrm{K})$, sulphur $(\mathrm{S})$, sodium $(\mathrm{Na})$, phosphor $(\mathrm{P})$ and zinc $(\mathrm{Zn})$ was lower for MS patients. No significant differences were found in the concentration levels of boron $(\mathrm{B})$, barium $(\mathrm{Ba})$, manganese $(\mathrm{Mn})$, molybdenum $(\mathrm{Mo})$, lead $(\mathrm{Pb})$, tin $(\mathrm{Sn})$, nickel $(\mathrm{Ni})$, titanium $(\mathrm{Ti})$ and vanadium $(\mathrm{V})$ between MS patients and healthy controls. The level of plasma $\mathrm{Ca}, \mathrm{K}, \mathrm{Na}, \mathrm{S}, \mathrm{P}$ and $\mathrm{Zn}$ is markedly decreased in MS patients whereas the level of $\mathrm{Cu}$ and $\mathrm{Si}$ increased. The level of the toxic metal cadmium $(\mathrm{Cd})$ was slightly but significantly lower in MS patients compared to controls. 
Table 2. Age-Adjusted Trace Elements Concentrations in Blood Plasma of Patients with Multiple Sclerosis (MS) and Control Subjects without MS

\begin{tabular}{|c|c|c|c|}
\hline Characteristic & $\begin{array}{c}\text { MS } \\
(\mathrm{N}=55)\end{array}$ & $\begin{array}{c}\text { No MS } \\
(\mathrm{N}=90)\end{array}$ & P-value \\
\hline & Mean (SEM) & Mean (SEM) & \\
\hline Silver $(\mathrm{Ag})(\mu \mathrm{g} / \mathrm{L})$ & $2.05(0.04)$ & $1.70(0.03)$ & $<0.001$ \\
\hline $\operatorname{Alminium}(\mathrm{Al})(\mu \mathrm{g} / \mathrm{L})$ & $3.00(0.05)$ & $2.75(0.04)$ & $<0.001$ \\
\hline Boron $(\mathrm{B})(\mu \mathrm{g} / \mathrm{L})$ & $1.15(0.009)$ & $1.16(0.007)$ & NS \\
\hline Barium $(\mathrm{Ba})(\mu \mathrm{g} / \mathrm{L})$ & $1.01(0.011)$ & $1.01(0.009)$ & NS \\
\hline Calcium $(\mathrm{Ca})(\mathrm{mg} / \mathrm{L})$ & $58.30(0.55)$ & $70.40(0.42)$ & $<0.001$ \\
\hline Cadmium $(\mathrm{Cd})(\mu \mathrm{g} / \mathrm{L})$ & $1.64(0.01)$ & $1.67(0.01)$ & $<0.01$ \\
\hline Chromium $(\mathrm{Cr})(\mu \mathrm{g} / \mathrm{L})$ & $1.17(0.02)$ & $1.09(0.02)$ & $<0.01$ \\
\hline Copper $(\mathrm{Cu})(\mu \mathrm{g} / \mathrm{L})$ & $1.67(0.03)$ & $1.06(0.02)$ & $<0.001$ \\
\hline Iron $(\mathrm{Fe})(\mu \mathrm{g} / \mathrm{L})$ & $4.13(0.03)$ & $4.25(0.02)$ & $<0.01$ \\
\hline Potassium $(\mathrm{K})(\mu \mathrm{g} / \mathrm{L})$ & $457.67(4.96)$ & $546.88(3.78)$ & $<0.001$ \\
\hline Magnesium $(\mathrm{Mg})(\mathrm{mg} / \mathrm{L})$ & $13.47(0.33)$ & $12.33(0.25)$ & $<0.1$ \\
\hline Manganese $(\mathrm{Mn})(\mu \mathrm{g} / \mathrm{L})$ & $0.94(0.009)$ & $0.96(0.007)$ & NS \\
\hline $\begin{array}{l}\text { Molybdenum (Mo) } \\
(\mu \mathrm{g} / \mathrm{L})\end{array}$ & $0.17(0.06)$ & $0.08(0.04)$ & NS \\
\hline Sodium $(\mathrm{Na})(\mu \mathrm{g} / \mathrm{L})$ & $\begin{array}{c}2644.89 \\
(17.66)\end{array}$ & $2783.16(13.46)$ & $<0.001$ \\
\hline Nickel $(\mathrm{Ni})(\mu \mathrm{g} / \mathrm{L})$ & $0.016(0.012)$ & $0.001(0.009)$ & NS \\
\hline Phosphorus (P) (mg/L) & $271.31(2.61)$ & $300.49(1.97)$ & $<0.001$ \\
\hline Lead $(\mathrm{Pb})(\mu \mathrm{g} / \mathrm{L})$ & $0.96(0.02)$ & $0.94(0.01)$ & $\mathrm{NS}$ \\
\hline Sulfur $(\mathrm{S})(\mathrm{mg} / \mathrm{L})$ & $250.10(2.03)$ & $273.5(1.55)$ & $<0.001$ \\
\hline Antimony $(\mathrm{Sb})(\mu \mathrm{g} / \mathrm{L})$ & $2.43(0.06)$ & $2.09(0.04)$ & $<0.001$ \\
\hline Silicon $(\mathrm{Si})(\mu \mathrm{g} / \mathrm{L})$ & $177.81(2.30)$ & $152.51(1.75)$ & $<0.001$ \\
\hline Tin $(\mathrm{Sn})(\mu \mathrm{g} / \mathrm{L})$ & $46.75(0.95)$ & $47.03(0.72)$ & $\mathrm{NS}$ \\
\hline Titanium $(\mathrm{Ti})(\mu \mathrm{g} / \mathrm{L})$ & $28.94(0.68)$ & $29.42(0.52)$ & NS \\
\hline Vanadium $(\mathrm{V})(\mu \mathrm{g} / \mathrm{L})$ & $35.66(0.81)$ & $34.84(0.62)$ & NS \\
\hline Zinc $(\mathrm{Zn})(\mu \mathrm{g} / \mathrm{L})$ & $235.20(2.63)$ & $288.11(2.01)$ & $<0.001$ \\
\hline
\end{tabular}

Note: Age-adjusted means were calculated using general linear models, $\mathrm{SEM}=$ standard error of the mean; $\mu \mathrm{g} / \mathrm{L}=$ micrograms $/$ litre; $\mathrm{mg} / \mathrm{L}=$ milligrams/litre; $\mathrm{NS}=$ non-significant.

To determine the independent predictors of the MS a forward stepwise binary logistic regression was performed to test 8 predictor variables: age, $\mathrm{Ca}$, $\mathrm{K}, \mathrm{S}, \mathrm{Na}, \mathrm{P}$ and $\mathrm{Zn}$ (included as continuous variables) and gender. The dependent variable was the MS (present, absent). Younger age (OR 0.89 (95\% CI: 0.81, 0.98), lower Ca (OR 0.74 (95\% CI: 0.62, 0.88) and Zn level (OR 0.89 (95\% CI: 0.84, 0.96) significantly increased the risk of MS.

The ROC curves for the MS for $\mathrm{Ca}, \mathrm{K}, \mathrm{S}, \mathrm{Na}, \mathrm{P}$ and $\mathrm{Zn}$ are shown in Figure 1. The areas under the ROC curves were 0.956 (95\% CI: 0.912, 0.999) for $\mathrm{Ca}, 0.954$ (95\% CI: $0.918,0.990)$ for K, 0.954 (95\% CI: $0.923,0.984)$ for Zn, 0.862 (95\% CI: $0.798,0.926)$ for $\mathrm{Na}, 0.894$ (95\% CI: $0.843,0.945)$ for P, and 0.755 (95\% CI: $0.673,0.838)$ for S. All elements were significant predictors for risk of MS $(\mathrm{P}<0.001)$. $\mathrm{Zn}, \mathrm{K}$ and $\mathrm{Ca}$ had a similar area and larger than that of $\mathrm{Na}, \mathrm{P}$ and $\mathrm{S}$. 
Figure 1. Receiver Operating Characteristic Curves for Calcium (Ca), Potassium $(K)$, Zinc (Zn), Phosphor (P), Sodium (Na) and Sulfur (S) for Prediction of MS

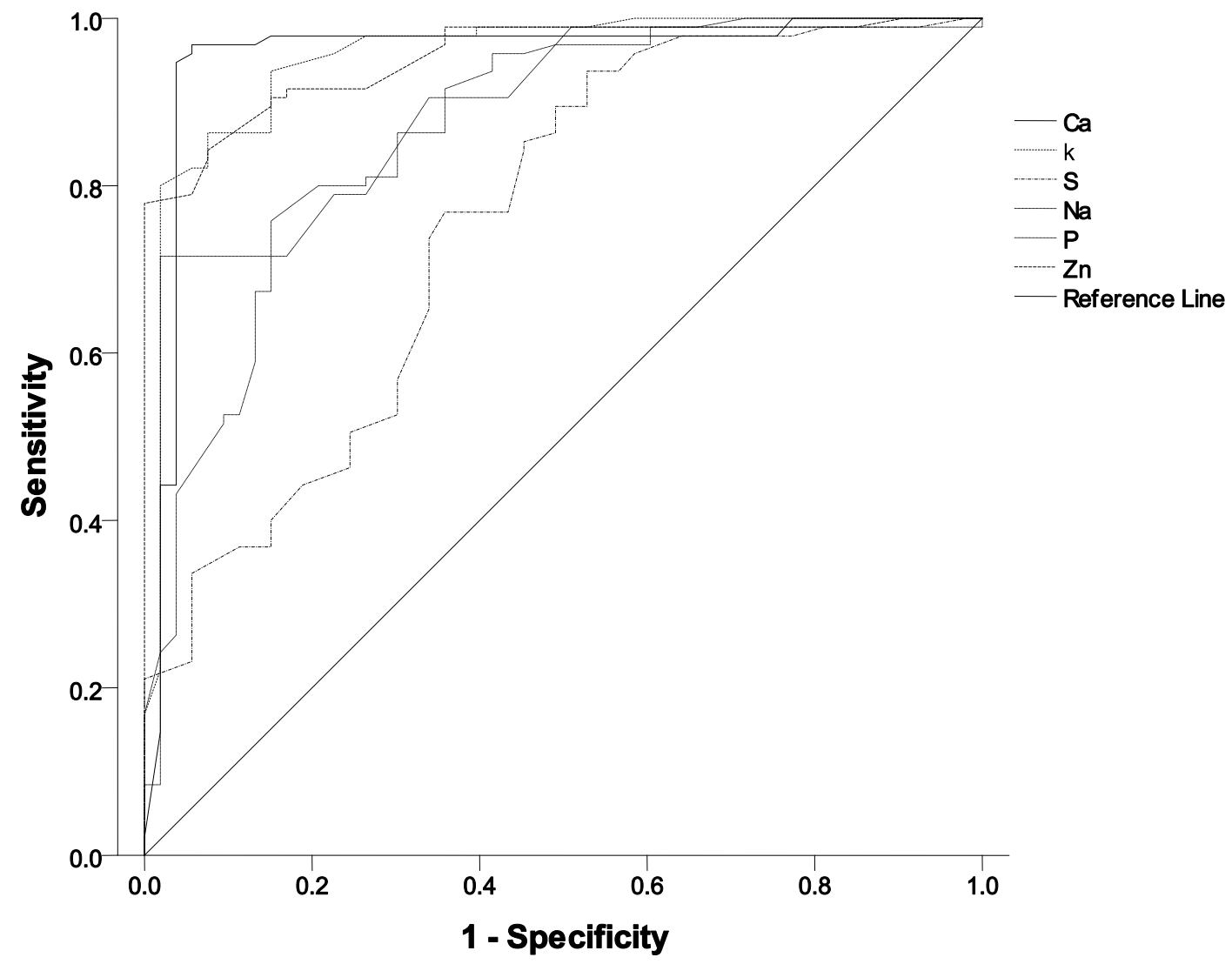

Notes: The estimates of the area under the ROC curves and their $95 \%$ confidence intervals are shown. Area under the curve (95\% confidence interval): Calcium - 0.956 (0.912, 0.999); Potassium - 0.954 (0.918, 0.990); Zinc - 0.954 (0.923, 0.984); Phosphor - 0.894 (0843, 0.945); Sodium - $0.862(0.798,0.926)$; Sulfur - $0.755(0.673,0.838)$.

These six elements were correlated with each other and the strongest Pearson correlation coefficients were found between $\mathrm{Ca}$ and $\mathrm{K}$ and the weakest ones were between $\mathrm{S}$ and $\mathrm{Na}$ (Table 3 ).

Plasma Ba $(\mathrm{r}=0.385, \mathrm{P}<0.01), \mathrm{Ca}(\mathrm{r}=0.354, \mathrm{P}<0.05), \mathrm{Sn} \quad(\mathrm{r}=0.328$, $\mathrm{P}<0.05)$, and $\mathrm{Cd}(\mathrm{r}=0.328, \mathrm{P}<0.05)$ were correlated with the disability of the MS patients as quantified on EDSS. No significant correlation was found between levels of each trace element and disease duration.

Table 3. Correlation Coefficients between Trace Elements

\begin{tabular}{|l|c|c|c|c|c|c|}
\hline \multicolumn{1}{|c|}{ Variables } & Ca & K & S & Na & P & Zn \\
\hline Calcium $(\mathrm{Ca})(\mathrm{mg} / \mathrm{L})$ & 1 & $0.729^{*}$ & $0.425^{*}$ & $0.511^{*}$ & $0.600^{*}$ & $0.702^{*}$ \\
\hline Potassium $(\mathrm{K})(\mu \mathrm{g} / \mathrm{L})$ & & 1 & $0.451^{*}$ & $0.400^{*}$ & $0.567^{*}$ & $0.683^{*}$ \\
\hline Sulfur $(\mathrm{S})(\mathrm{mg} / \mathrm{L})$ & & & 1 & $0.299^{*}$ & $0.341^{*}$ & $0.551^{*}$ \\
\hline Sodium $(\mathrm{Na})(\mu \mathrm{g} / \mathrm{L})$ & & & & 1 & $0.406^{*}$ & $0.378^{*}$ \\
\hline Phosphor $(\mathrm{P})(\mathrm{mg} / \mathrm{L})$ & & & & & 1 & $0.558^{*}$ \\
\hline
\end{tabular}

Note: $* \mathrm{P}<0.001$. 


\section{Discussion}

The main finding in this study is the decreased level of $\mathrm{Ca}, \mathrm{K}, \mathrm{S}, \mathrm{Na}, \mathrm{P}$ and $\mathrm{Zn}$ and the increased level of $\mathrm{Cu}$ and $\mathrm{Si}$ in blood plasma from patients with MS. Whether these decreased trace element levels are a cause or effect of the MS it is impossible to state at present, however it seems more plausible that the disturbance in trace element levels in blood plasma may be due to the use of steroids and/or interferon beta in the course of the disease. These decreased trace element levels may also be related to the type of treatment which was prescribed. To the best of our knowledge, this is the first study comparing the 24 trace elements in the plasma of MS patients and compared with healthy volunteers. A limited number of studies have been published on the possible role of trace elements in MS (Melo et al. 2003, Mauch et al. 1995, Valberg et al. 1989, Dore-Duffy et al. 1983, Palavinskas and Schulten 1984, Palm and Hallmans 1982, LeVine et al. 1999, Rieder et al. 1983, Exley et al. 2006, Forte et al. 2005b) and the results are inconsistent. Discrepancies among studies investigating the metals and trace elements in patients with MS may be attributable to small sample sizes that resulted in insufficient statistical power to detect some relationships in the individual studies. Measurements of trace elements will depend upon the methodological factors, the definition of the MS used, and the composition of the control group by age, gender, ethnicity, and uncontrolled confounders, making comparisons between studies of limited values.

Melø et al. (2003) found an increase of $\mathrm{Cu}$ and a decrease of Mn levels in cerebrospinal fluid (CSF) in MS patients compared to controls, and no differences were found for $\mathrm{Zn}$. Normal values for $\mathrm{Fe}, \mathrm{K}, \mathrm{Na}, \mathrm{Rb}, \mathrm{Ca}$ and $\mathrm{Mg}$ have been reported in blood or CSF (Palaviskas and Schulten 1984, Palm and Hallmans 1982, LeVine et al. 1999, Rieder et al. 1983, Exley et al. 2006). Recently, Tamburo et al. (2015) found a lower concentration of Al, rubidium and a higher concentration of uranium in scalp hair samples in MS patients compared to controls. We observed lower concentrations of plasma $\mathrm{Zn}$ in MS patients. Zn has an important role in the inhibition of potentially destructive immune reactions against the $\mathrm{T}$ lymphocytes, and in the predisposing inflammatory responses of MS. It is also an antioxidant which protects the cell membranes and myelin. Previous studies on plasma $\mathrm{Zn}$ levels in MS patients were contradictory with decreased (Palm and Hallmans 1982, Wong et al. 1980, Masoud and Fakharian 2007, Weinsmann et al. 1982), normal (Melo et al. 2003, Rieder et al. 1983, Halliwell 1992), and increased (Dore-Duffy et al. 1983) concentration reported. The Serum $\mathrm{Zn}$ level could decrease in MS patients who received corticosteroid therapy (Al-Zubadi 2012), while its levels had been reported to increase in the patients who received interferon beta (Sato et al. 1996). In the present study, plasma Cu levels increased in the MS group as compared to the control group, which was agreeable with what had been reported in the other studies (Melo et al. 2003, Wong et al. 1980). The increase in the plasma $\mathrm{Cu}$ concentration was found to decrease the $\mathrm{Zn}$ absorption. Several studies have proved the existence of competition in the intestinal 
absorption and the inverse relationship between plasma $\mathrm{Cu}$ and $\mathrm{Zn}$ concentration (Al-Zubadi 2012, Sato et al. 1996). This finding contrasts with the finding of other studies (Rieder et al. 1983) which concluded that the blood concentration of $\mathrm{Cu}$ was normal in MS patients.

The nervous system and in particular the myelin sheath seems to be more susceptible to oxidative damage than other organs, partly due to its high metabolic activities and rather marginal antioxidant defence systems and a relatively high content of vulnerable fatty constituents (Halliwell 2006). The progressive myelin destruction that characterizes MS may be accelerated by oxidative stress. $\mathrm{Zn}$ has an important role in the initiation of potentially destructive immune reactions against the $\mathrm{T}$ lymphocytes, and in the predisposing inflammatory responses of MS. It is also an antioxidant which protects the cell membranes and myelin.

In the present study, the MS patients showed a slightly but significantly lower plasma concentration of cadmium, iron, sodium, phosphorus, sulphur and higher plasma concentration of silver, aluminium, chromium, magnesium, antimony and silicon. Are these observations just an epiphenomenon of other pathogenic mechanisms or can they actually contribute to the pathogenesis of MS? We do not have an explanation for this associations and this warrant further study.

Our study has several limitations. First, the number of subjects is relatively small. Secondly, the control group in this study was recruited from employees of the Isfahan University of Medical Sciences and may not represent healthy individuals from the community. In particular, the control group was not matched for age with MS patients, although we adjusted for age. However, after age- and gender-adjustment the differences were not statistically significant in some trace elements. As a case-control study, the present analysis is limited in its ability to elucidate causal relationships between trace element concentrations and MS.

In summary, our study indicates that the decreased levels of $\mathrm{Ca}, \mathrm{K}, \mathrm{S}, \mathrm{Na}$, $\mathrm{P}$ and $\mathrm{Zn}$ in the plasma of MS patients may indicate an active role of these trace elements in the course of MS. This warrants further study.

\section{Acknowledgments}

This work was partially supported by funds from Isfahan University of Medical Sciences, Iran. This research was performed as a part of the academic activity of the university. All authors vouch for the veracity and completeness of the reported data, and all authors contributed to various aspects of the study design, data gathering and analysis, and preparation of the manuscript. 


\section{References}

Al-Zubadi M (2012) The effect of interferon beta-1b and methylprednisolone treatment on the serum trace elements in Iraqi patients with multiple sclerosis. Journal of Clinical and Diagnostic Research 6: 994-998.

Bomboi G, Marchione F, Sepe-Monti M, De Carolis A, Bianchi V, Medda E, et al. (2005) Correlation between metal ions and clinical findings in subjects affected by Alzheimer's disease. Annali dell'Istituto Superiore di Sanità 41(2): 205-212.

Clanet MG, Brassat D (2000) The management of multiple sclerosis patients. Current Opinion in Neurology 13(3): 263-270.

Dore-Duffy P, Catalanotto F, Donaldson JO, Ostrom KM, Testa MA (1983) Zinc in multiple sclerosis. Annual Neurology 14(4): 450-454.

Exley C, House ER (2010) Aluminium in the human brain. Monatshefte für Chemie 142: 357-363.

Exley C, Mamutse G, Korchazhkina O, Pye E, Strekopytov S, Polwart A, Hawkins C (2006) Elevated urinary excretion of aluminium and iron in multiple sclerosis. Multiple Sclerosis 12(5): 533-540.

Forte G, Alimonti A, Violante N, Di Gregorio M, Senofonte O, Petrucci F, et al. (2005) Calcium, copper, iron, magnesium, silicon and zinc content of hair in Parkinson's disease. Journal of Trace Elements in Medicine and Biology 19(23): $195-201$.

Forte G, Visconti A, Santucci S, Ghazaryan A, Figà-Talamanca L, Cannoni S, et al. (2005) Quantification of chemical elements in blood of patients affected by multiple sclerosis. Annali dell'Istituto Superiore di Sanità 41(2): 213-216.

Halliwell B (1992) Reactive oxygen species and the central nervous system. Journal of Neurochemistry 59(5): 1609-1623.

Halliwell B (2006) Oxidative stress and neurodegeneration: where are we now? Journal of Neurochemistry 97(6): 1634-1658.

Iregren A, Sjogren B, Gustafsson K, Hagman M, Nylén L, Frech W, et al. (2001) Effects on the nervous system in different groups of workers exposed to aluminium. Occupational and Environmental Medicine 58(7): 453-460.

Kienzl E, Jellinger K, Stachelberger H, Linert W (1999) Iron as catalyst for oxidative stress in the pathogenesis of Parkinson's disease. Life Sciences 65(18-19): 19731976.

Kurtzke JF (1983) Rating neurologic impairment in multiple sclerosis: an expanded disability status scale (EDSS). Neurology 33(11): 1444-1452.

LeVine SM, Lynch SG, Ou CN, Wulser MJ, Tam E, Boo N (1999) Ferritin, transferrin and iron concentrations in the cerebrospinal fluid of multiple sclerosis patients. Brain Research 821(2): 511-515.

Masoud SA, Fakharian E (2007) Assessment of Serum Magnesium, Copper, and Zinc levels in Multiple Sclerosis (MS) patients. Iranian Journal of Psychiatry and Behavioural Sciences 1: 38-41.

Mauch E, Gebhardt A, Stiefel T (1995) Trace metals in multiple sclerosis. Neurology Psychiatry and Brain Research 3: 149-153.

Melø TM, Larsen C, White LR, Aasly J, Sjøbakk TE, Flaten TP, et al. (2003) Manganese, copper, and zinc in cerebrospinal fluid from patients with multiple sclerosis. Biological Trace Element Research 93(1-3): 1-8.

Monroe RK, Halvorsen SW (2009) Environmental toxicants inhibit neuronal Jak tyrosine kinase by mitochondrial disruption. Neurotoxicology 30(4): 589-598. 
Nicoletti A, Patti F, Lo Fermo S, Messina S, Bruno E, Quattrocchi G, et al. (2011) Increasing frequency of multiple sclerosis in Catania, Sicily: a 30-year survey. Multiple Sclerosis 17(3): 273-280.

Palavinskas P, Schulten HR (1984) Determination of electrolytes and trace metals in the cerebrospinal fluid of patients with multiple sclerosis and healthy subjects. Trace Elements in Medicine 1: 29-34.

Polman CH, Reingold SC, Edan G, Filippi M, Hartung HP, Kappos L, et al. (2005) Diagnostic criteria for multiple sclerosis: revisions to the "McDonald Criteria". Annual of Neurology 58(6): 840-846.

Palm R, Hallmans G (1982) Zinc and copper in multiple sclerosis. Journal of Neurology Neurosurgery Psychiatry 45(8): 691-698.

Richards RG, Sampson FC, Beard SM, Tappenden P (2002) A review of the natural history and epidemiology of multiple sclerosis: implications for resource allocation and health economic models. Health Technology Assessment 6(10): 1-73.

Rieder HP, Schoettli G, Seiler H (1983) Trace elements in whole blood of multiple sclerosis. European Neurology 22(2): 85-92.

Ryan DE, Holzbecher J, Stuart DG (1978) Trace elements in scalp-hair of persons with multiple sclerosis and of normal individuals. Clinical Chemistry 24(11): 1996-2000.

Sato M, Yakami J, Oguro T, Yoshida T, Nomura N, Nakajima K (1996) Methallothionein synthesis is induced by interferon $\alpha / \beta$ in mice with various zinc status. The Tohoku Journal of Experimental Medicine 178(3): 241-250.

Sayre LM, Perry G, Atwood CS, Smith MA (2000) The role of metals in neurodegenerative diseases. Cellular \& Molecular Biology 46(4): 731-741.

Schulten HR, Monkhouse PB, Achenbach C, Ziskoven R (1983) Determination of rubidium in human serum. Experientia 39(7): 736-738.

Smith DK, Feldman EB, Feldman DS (1989) Trace element status in multiple sclerosis. American Journal of Clinical Nutrition 50(1): 136-140.

Tamburo E, Varrica D, Dongarrà G, Grimaldi LM (2015) Trace elements in scalp hair samples from patients with relapsing-remitting multiple sclerosis. PLoS One 10(4): e0122142.

Valberg LS, Flanagan PR, Kertesz A, Ebers GC (1989) Abnormalities in iron metabolism in multiple sclerosis. Canadian Journal of Neurological Sciences 16(2): 184-186.

Valera P, Zavattari P, Albanese S, Cicchella D, Dinelli E, Lima A, et al. (2014) A correlation study between multiple sclerosis and type 1 diabetes incidences and geochemical data in Europe. Environmental Geochemistry and Health 36(1): 79-98.

Vinceti M, Solovyev N, Mandrioli J, Crespi CM, Bonvicini F, Arcolin E, et al. (2013) Cerebrospinal fluid of newly diagnosed amyotrophic lateral sclerosis patients exhibits abnormal levels of selenium species including elevated selenite. Neurotoxicity 38: 25-32.

Wallwork JC, Sandstead HH (1993) Zinc and brain function. Progress in clinical and biological research 380: 65-80.

Weinsmann K, Asboe-Hansen G, Secher L (1982) Plasma zinc levels in multiple sclerosis. Metabolic, pediatric, and systemic ophthalmology 6(2): 137-139.

Wong Jr, EK, Enomoto H, Leopold IH, Fleischer EB, Schoon DV, Fender D, et al. (1980) Plasma zinc levels in multiple sclerosis. Metabolic, pediatric, and systemic ophthalmology 4(1): 3-8. 